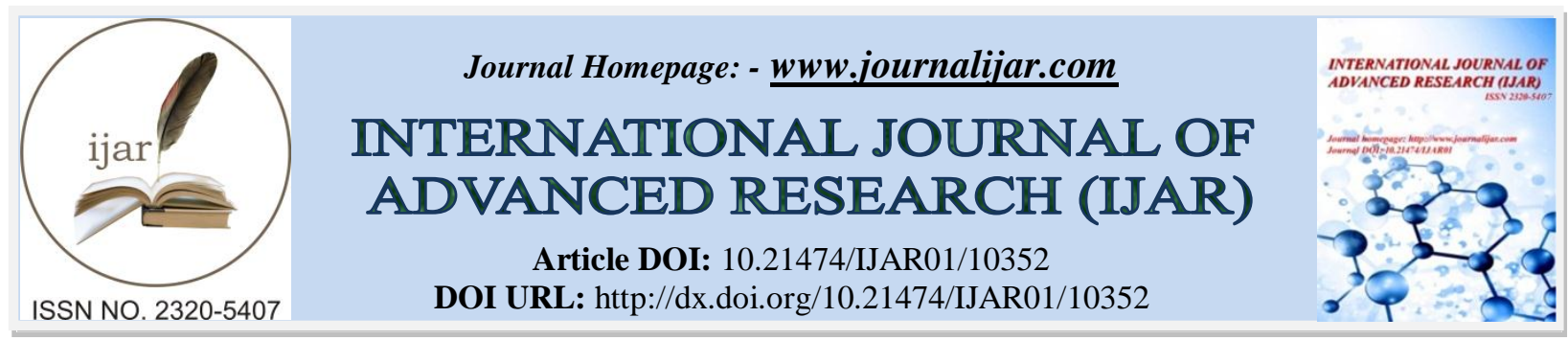

RESEARCH ARTICLE

\title{
IMMUNOMODULATION OF LACTOBACILLUS PLANTARAM EXPRESSING PORCINE ROTAVIRUS VP6
}

\author{
Seria Masole Shonyela ${ }^{1,2}$, Wentao Yang ${ }^{1}$, Guilian Yang $^{1}$ and Chunfeng Wang ${ }^{1}$
}

1. College of Animal Science and Technology Jilin University, Changchun, 13018.

2. Ministry of Agriculture, Livestock and Fisheries, P.O. Box 9152, Veterinary Complex, 131 Nelson Mandela Rd, Dar es Salaam, Tanzania.

\section{Manuscript Info}

\section{Manuscript History}

Received: 27 November 2019

Final Accepted: 30 December 2019

Published: January 2020

\begin{abstract}
Rotaviruses are members of the family Reoviridae. Depending on their particular inner capsid protein sequences, porcine rotaviruses are categorized into groups A, B and C. Lactic acid bacteria (LAB) are the common term for bacteria that produce a large amount of lactic acid and ferment carbohydrates. We constructed a Lactobacillus plantarum strain with surface displayed VP6, named NC8-pSIP409-pgsA-VP6Dcpep The adhesion and invasion ratios of NC8-pSIP409-pgsA-VP6Dcpep on BMDCs were $36.17 \%$ and $2.23 \%$, respectively, which were 1.56 fold and 2.42 fold increased compared with empty vector group. Furthermore, NC8-pSIP409-pgsA-VP6-Dcpep strain harboring a eukaryotic plasmid pValac-GFP was co-cultured with BMDCs for $36 \mathrm{~h}$ and GFP expression in BMDCs was detected by FCM to determine the delivery efficiency of $\mathrm{pValac}-\mathrm{GFP}$. The results showed that the strain could significantly enhance GFP expression in BMDCs $(\mathrm{P}=0.0110)$. The mice were immunized using the above strains harboring pValacGFP and the oral administration resulted in efficient expression of GFP in both PPs andMLN at different times after the last administration. In addition, the NC8-pSIP409-pgsA-VP6-Dcpep strain significantly promoted the differentiation and maturation of DCs, the percentages of IL-4+and IL-17A+ of CD4+T cells in MLN, as well as production of B220+ IgA+ B cells in the PPs.
\end{abstract}

Copy Right, IJAR, 2020,. All rights reserved.

\section{Introduction:-}

Rotaviruses are members of the family Reoviridae. Depending on their particular inner capsid protein sequences, porcine rotaviruses are categorized into groups A, B and C (17). Rotaviruses have a nonenveloped, double-stranded RNA genome that is composed of 11 segments enclosed by a triple-layered icosahedral capsid, (16, 22, 23, 28). The neutralizing antibodies conferring protection in pigs against porcine rotavirus infection can be induced by the VP6 protein. The main source of acute diarrhea in piglets is porcine rotaviruses, which can cause high rates of mortality and morbidity $(13,35,26,1,21,14)$. In both pre- and post-weaning pigs, rotavirus Group A is the main source of rotavirus-associated diarrhea and accounts for $54 \%$ and $45 \%$ of the diarrhea experienced in those populations of pigs, respectively (17). Some research has reported that in commercial pig farms, $89 \%$ of all rotavirus-associated diarrhea can be attributed to group A rotavirus infections (33). Rotavirus outbreaks are difficult to prevent because they are transmitted via the fecal oral route and can survive in the environment for a long period of time. Replication 
of the virion takes place in the intestinal villi in epithelial cells and destroys enterocytes mainly in the ileum and jejunum, leading to villous atrophy $(10,30,8,19)$. In addition, in the affected regions, nutrients cannot be absorbed or digested, causing severe malabsorption $(10,30,8,19)$. Porcine rotavirus VP6 antigens are the most potential antigen presenting cells, which can induce effective CTL response in antiviral infection. The most important structural protein in rotavirus is VP6 particles located on the outer surface of single-shelled particles, as well, VP6 is recognized as a subgroup antigen(12). VP6 is necessary for polymerase activity and for maintaining the appropriate structure of the viral core. VP6 myristylation is necessary for virus particle configuration in addition to the ER membrane for promising to targeting single-shelled particles (9). VP6 it is the mainly often used in diagnostic assays to detect PRV because is both highly antigenic and immunogenic (32). Herein, we expressed the VP6 gene from a PRV Chinese isolate DN30209 by cloning this gene into a bacterial expression system. We then generated rabbit polyclonal anti-serum and ascertained its immunoreactivity to VP6 protein. Using the anti-VP6 antibody, we established a differentiating ELISA for PRV. These experiments provided basis for determination of PRV.

Lactic acid bacteria (LAB) are the common term for bacteria that produce a large amount of lactic acid and ferment carbohydrates $(4,6,7,34,15)$. LAB is internationally measured as food grade safe microorganisms due to long-term colonization animals or of humans and a advantageous function in hosts. Lactobacillus plantarum is an instrument to express heterologous proteins due to its safety, easy cultivation, ease of operation, and other benefits, or in the vaccine field can be regarded as alive vector-delivering antigen $(29,36)$. L. plantarum NC8 is a type of bacterium lacticum separated from ensilage, compared with bacterium lacticum from animals; L. plantarum NC8 has a high sense of resistance and is more appropriate for expressing foreign proteins as host bacteria $(2,37)$. It has been reported that poly- $\gamma$-glutamic acid synthetase A (pgsA) of the polyglutamic acid (PGA) synthetase system from Bacillus subtilis can serve as a bacterial surfacedisplayed system (25), and heterologous proteins on the surface of the lactobacillus strains using a pgsA system could improve immune responses $(11,38)$. In the study by (5) a truncated PgsA bacterial surface-displayed system (pSIP409-pgsA') was constructed and used in this study.

In this study, anti-VP6 antibodies used to determine the immunoreaction and the localization of the VP6 antigen on the surface of L. plantarum NC8 cells was detected by flow cytometry and fluorescence microscopy. In additional investigation of the humoral, cellular immune and mucosal responses in mice after oral immunization with recombinant NC8-pSIP409-pgsA-VP6-Dcpep was done. in addition, the protective effect of the recombinant NC8pSIP409-pgsA-VP6-Dcpep against porcine rotavirus challenge was determined based on the virus titer, weight loss, and histoparhological from infected mice.

This study intends to draw lessons from this idea and further anchor the expression of VP6 on the surface of Lactobacillus plantarum cell wall by using the anchoring sequence LysM (24), which can be anchored on the cell wall by Lactobacillus plantarum itself, so as to enhance the ability of Lactobacillus plantarum to target DCs and enhance the immune response of organisms.

In this study, a Lactobacillus plantarum NC8 strain was constructed which can not only increase the ability of adhesion and invasion to BMDCs in vitro, but also enhance the immunity in vivo.

\section{Materials And Methods:-}

Materials:-

\section{Gene fragments, strains and plasmid vectors:-}

The NC8 sensitivity of Lactobacillus plantarum was prepared and preserved by Jilin Animal Microecological Preparations and Engineering Research Center of Jilin Agricultural University. Porcine rotavirus isolate DN30209 VP6 gene was kindly purchased from Genwiz.co and provided by Laboratory of Jilin Provincial Engineering Research Center of Animal Probiotics.

\section{Laboratory animals:-}

Female C57BL/6 mice and BALB/c mice aged 5-6 weeks were purchased from Beijing Huafukang Biotechnology Co., Ltd.

\section{Method:-}

PCR amplification and cloning of the target gene VP6 
The conditions of PCR amplification were as follows: pre-denaturation at $94^{\circ} \mathrm{C}$ for 5 minutes, denaturation at $94^{\circ} \mathrm{C}$ for 30 seconds, annealing at $55^{\circ} \mathrm{C}$ for 30 seconds, extension at $72^{\circ} \mathrm{C}$ for 30 cycles and extension at $72^{\circ} \mathrm{C}$ for 10 minutes. After the reaction was finished, the 2 L PCR product was electrophoretic on $0.8 \%$ agarose gel.

Recovery and digestion of PCR products

DNA gel recovery kit was used to recover the PCR products. The specific steps were carried out according to the instructions of the kit.

The purified PCR products were digested by double enzyme digestion.

Enzyme digestion products were purified according to the instructions of DNA purification and recovery kit.

Construction of Recombinant Plasmid pSIP409-pgsA-VP6-Dcpep

Connection of the target gene VP6 with vector pSIP409-pgsA

Connector was connected overnight at 16 and transformed into E. coli BL21 competent cells the next day. Ice bath was 30 minutes, $42^{\circ} \mathrm{C}$ water bath was 90 seconds, ice bath was 6 minutes, and $600 \mu \mathrm{L}$ liquid culture medium was added to shaking bed at $37^{\circ} \mathrm{C}, 220 \mathrm{rpm}, 1 \mathrm{~h} .100 \mathrm{~L}$ bacterial solution was taken out and applied to solid culture medium containing kanamycin (Kan+, final concentration was $50 \mathrm{ug}$ )./ In mL. After overnight incubation in $37^{\circ} \mathrm{C}$ incubator, the colonies were cultured overnight in a shaker at $37^{\circ} \mathrm{C}$ and $180 \mathrm{rpm}$. The monoclones were selected and cultured in $5 \mathrm{~mL}$ LB liquid medium (Kan+). Plasmid extraction kit was used to extract the plasmid according to the instructions.

Enzyme digestion identification of recombinant plasmid pSIP409-pgsA-VP6-Dcpep

The $2 \mathrm{H}$ was digested by 37 in a water bath. The enzyme products were detected by $0.8 \%$ agarose gel electrophoresis. And sent to Jilin Province Kumei Biotechnology Co., Ltd. for sequencing.

Induced Expression, Purification and SDS-PAGE Detection of Target Protein VP6

\section{Induced expression of target protein:-}

The strain pSIP409-pgsA-VP6-Dcpep (BL21) at $-80^{\circ} \mathrm{C}$ was extracted and activated in $5 \mathrm{~mL}$ liquid LB medium $(\mathrm{Kan}+)$ at a ratio of 1:100, then in $100 \mathrm{~mL}$ liquid LB medium (Kan+) at a ratio of 1:100. The strain was cultured in shaking bed at $37^{\circ} \mathrm{C}$ and $180 \mathrm{rpm}$. When its OD value reached 0.3 , IPTG inducer (final concentration $500 \mathrm{ug} / \mathrm{mL}$ ) was added. ) Induced overnight in a shaker.

\section{Protein-like treatment:-}

The overnight induction liquid was put into the $50 \mathrm{~mL}$ centrifugal tube of sterilization, centrifuged for 10 minutes at $5000 \mathrm{rpm}$ at $4^{\circ} \mathrm{C}$. The supernatant and precipitation after centrifugation were collected by ultrasonic crusher for 10 minutes on ice and 10 minutes at $5000 \mathrm{rpm}$ at $4^{\circ} \mathrm{C}$

\section{Purification of target protein:-}

The Ni-Agarose medium was fully mixed, and the mixture of $200 \mu \mathrm{L}$ (50\% medium concentration) medium and preservative solution was added to the column with a pre-placed sieve plate; the column was washed with $1 \mathrm{~mL}$ deionized water for three times; the column was washed with $1 \mathrm{~mL}$ new binder solution for three times; the supernatant sample was taken out by gravity; the column was washed with $1 \mathrm{~mL}$ binder solution. To collect and preserve the penetrating fluid, and then to collect and preserve the penetrating fluid (containing His labeled protein) with a new eluent column of $500 \mu \mathrm{L}$. The column was washed once with $500 \mu \mathrm{L}$ binding solution, $1 \mathrm{~mL}$ deionized water and $500 \mu \mathrm{L}$ self-contained $20 \%$ ethanol, and finally the leak at the bottom of the column was blocked. The medium was submerged by adding $500 \mu \mathrm{L} 20 \%$ ethanol and stored at $4^{\circ} \mathrm{C}$. The protein samples washed out by the eluent were taken out and mixed with $40 \mu \mathrm{L} 5 * \mathrm{SDS}$ buffer, boiled at $100^{\circ} \mathrm{C}$ for $5 \mathrm{~min}$, centrifuged at $12000 \mathrm{~m}$ for 2 min. SDS-PAGE was detected.

\section{SDS-PAGE detection:-}

$12 \%$ separation glue and 5\% concentration glue were respectively allocated. The separation glue and concentrated glue should be solidified for about 30min; take the upper $15 \mu \mathrm{L}$ to carry out the sample preparation, then carry out electrophoresis with $80 \mathrm{~V}$ voltage, end the electrophoresis when the bromine phenol blue moved to the bottom of the 
gel, remove the gel, put it in the Coomassie brilliant blue staining solution, and put it in the rocking bed to dye $45 \mathrm{~min}$. Use decolorizing solution to decolorize, change decoloring solution frequently, decolorize overnight, and then carry out on-line detection.

\section{Detection of target protein concentration by BCA:-}

The concentration of VP6 protein was determined according to the instructions of Biyuntian BCA protein concentration determination kit, and the absorbance of A562 was determined by enzyme labeling instrument.

Indirect ELISA for Detecting Antibody Titer of Polyclonal Antibody:-

The purified VP6 protein was diluted with $0.1 \mathrm{M}$ NaHCO $3(\mathrm{PH}=9.6)$ to reach the final concentration of $2 \mathrm{~g} / \mathrm{mL}$, and $100 \mathrm{~L}$ protein diluent was added to each hole of 96 -well ELISA plate, which was packed overnight at $4^{\circ} \mathrm{C}$. PBST was washed three times and $1 \%$ BSA PBS was added to each hole, which was sealed at $37^{\circ} \mathrm{C}$ for $1 \mathrm{~h}$; PBST was washed three times and rabbit anti-VP6 serum was prepared. Beginning with the dilution ratio of 1:4000, dilution was carried out in turn: 1:8000, 1:16000, 1:32000, 1:64000, 1:128000, 1:516000, $100 \mu \mathrm{L}$ per hole for 1 hour, PBST was washed three times, HRP-labeled goat anti-rabbit IgG was diluted at 1:1000 for 30 minutes, STPB was washed three times again, TMB L was added to each hole. The color was developed and terminated by adding $20 \% \mathrm{H} 2 \mathrm{SO} 4$ solution. The detection was carried out at OD450 wavelength by enzyme labeling instrument.

\section{Detection of lactic acid bacteria NC8-pSIP409-pgsA-VP6-Dcpep by Western-blot:-}

Proteins in the cell wall of Lactobacillus were extracted. Anti-His Tag Mouse Monoclonal Antibody (1:1000 dilution) was used as the first antibody, and goat anti-mouse $\lg \mathrm{G}$ antibody (1:1000 dilution) labeled with HRP was used as the second antibody for Western-blot detection.

\section{Detection of Lactic Acid Bacteria Targeting DCs to BMDCs:-} Coating Plate Method for Detecting the Rate of Adhesion to Invasion:-

BMDCs were isolated from female C57BL/6 mice aged 5-6 weeks. Immature DCs were collected on the 8th day. Trypan blue was used to stain and count the immature DCs. The BMDCs were spread into 24-well cell culture plate with $2 * 105$ cells/holes.

NC8-pSIP409 and NC8-pSIP409-pgsA-VP6-Dcpep strains frozen at - $80^{\circ} \mathrm{C}$ were separately delineated on the MRS solid plate containing Em, and then the monoclones were selected for monoclonal selection. The monoclones were transferred to the MRS liquid medium of $5 \mathrm{~mL}$. The anaerobic culture at $30^{\circ} \mathrm{C}$ was carried out until OD value was 0.3. SppIP, a $12.5 \mathrm{~L}$ inducible peptide, was added to induce overnight incubation. PBS was used to adjust the overnight incubation. The concentration of bacterial solution was $2 * 108 \mathrm{CFU} / 100 \mathrm{~L}$ for adhesion and invasion test.

Adhesion and invasion tests were divided into three groups: NC8-pSIP409, NC8-pSIP409-pgsA-VP6-Dcpep groups, each group had three multiple holes. In NC8-pSIP409-pgsA-VP6-Dcpep the anti-VP6 (antibody) group, with the final concentration of $2 \mathrm{ug} / \mathrm{mL}$ was added to each pore before hand, and cultured in 5\% $\mathrm{CO} 2$ incubator at $37 \mathrm{C}$ for 1 hour. In each group, the induced cultured strains NC8-pSIP409 and NC8-pSIP409-pgsA-VP6-Dcpep were added to BMDCs at the ratio of $\mathrm{MOI}=1000$ to detect the adhesion rate and invasion rate. The adhesion and invasion rates of each group were compared by colony counting.

\section{TEM Observation of Invasive Effect of Targeted Lactic Acid Bacteria on BMDCs:-}

The immature BMDCs collected on the 8th day were counted and laid on a 6-hole cell culture plate with 1.0 *106/mL per hole. The concentration of NC8-pSIP409 and NC8-pSIP409-pgsA-VP6-Dcpep was adjusted to 1.0 $* 109 \mathrm{CFU} / 200 \mu \mathrm{L}$. The $200 \mu \mathrm{L}$ corresponding bacterial solution was added to the cell culture plate with MOI=1000 for 2 hours. Meanwhile, empty cells were set as negative control and washed with PBS. Polyester was digested with $0.25 \%$ trypsin-EDTA, FBS was terminated, washed again with PBS and fixed overnight with $2.5 \%$ glutaraldehyde fixed solution. The samples were sent to Harbin Veterinary Research Institute of Chinese Academy of Agricultural Sciences for preparation. The invasive ability of targeted lactic acid bacteria to BMDCs was observed by transmission electron microscopy.

Detection of BMDCs Delivery Efficiency by aCD11c:-

In order to detect the plasmid delivery ability of VP6 expression in cells, immature BMDCs were collected on the 8th day. According to cell density, $2.0 * 105 / \mathrm{mL}$ cells were laid out in 24 -well cell culture plates, as follows: 
In order to remove extracellular bacteria, gentamicin was added for 2 hours, PBS was washed three times, and 1640 complete medium with $1 \mathrm{~mL}$ was added to each pore for 36 hours. Cells were collected in a $1.5 \mathrm{~mL}$ centrifugal tube at $42000 \mathrm{rpm} / 5 \mathrm{~min}$, and the supernatant was discarded. Wash $1 \mathrm{~mL} \mathrm{PBS}$ once, $42000 \mathrm{r} \mathrm{pm} / 5 \mathrm{~min}$, discard supernatant. Using $100 \mu \mathrm{L}$ PBS suspensions, each tube was stained with $10 \mu \mathrm{L}$ APC labeled anti-mouse VP6 antibody at room temperature for 30 minutes. PBS was washed twice, and the supernatant was discarded at $4 \sim 2000$ $\mathrm{rpm} / 5 \mathrm{~min}$. Fixation/permeabilization Solution with $250 \mu \mathrm{L}$ fixative was added to each hole and blended well. The supernatant was kept away from light for 20 minutes at ${ }^{\circ} \mathrm{C}$. The supernatant was discarded at $42000 \mathrm{rpm} / 5 \mathrm{~min}$, then added $1 \mathrm{~mL} 1 \mathrm{X}$ BD perm/wash buffer, 4 2000 rpm/5min, discarded the supernatant, washed twice, then washed twice with PBS, fixed volume to $300 \mu \mathrm{L}$.

\section{Plasmid delivery effect of VP6 expression in vivo:-}

In order to detect the plasmid delivery of lactic acid bacteria expressing VP6 in BALB/c mice, we immunized $\mathrm{BALB} / \mathrm{c}$ mice with targeted lactic acid bacteria containing GFP, and then detected the expression of GFP. The specific methods are as follows:

\section{Animal experiment group:-}

$27 \mathrm{BALB} / \mathrm{c}$ female mice aged 5-6 weeks, 9 in each group. The experiment was divided into three groups: PBS group, 409/pValac-GFP group and 409a/pValac-GFP group.

\section{Immunization procedure:-}

Each group of mice was immunized with 109 CFU/100 L by gavage for 3 consecutive days. The mice were killed at three time points of 1, 3 and 7 days after immunization, and 3 mice in each group at each time point were tested for related indicators. The MLN and P P junctions of mice in each group were obtained.

Blood was collected from eyeball, and the serum was put in refrigerator at $4^{\circ} \mathrm{C}$ for overnight. The serum was centrifuged at $4^{\circ} \mathrm{Cand} 4000 \mathrm{rpm}$ for 15 minutes, then the serum was extracted at $-80^{\circ} \mathrm{C}$ for reserve.

Spleen, MLN and P P knots were taken from the super-clean platform. 200 mesh steel mesh was placed in a $35 \mathrm{~mm}$ sterile dish, $1 \mathrm{~mL}$ of 1640 medium was added to the tissue and grinded. Cells were washed twice with 1640, and the supernatant was discarded. Spleen cells needed to lyse red blood cells with erythrocyte lysate, and then again. After washing, the cell suspension obtained through the membrane is the original solution. After dilution with PBS, the blood cell count plate is counted.

A segment of duodenum of mice was obtained and washed with PBS containing PMSF for $4000 \mathrm{rpm} / 15 \mathrm{~min}$. The supernatant was collected and frozen at $-80^{\circ} \mathrm{C}$.

Adjust the cell concentration of each sample to $1.0 * 106 / 100 \mu \mathrm{L}$, add $10 \mu \mathrm{L}$ APC labeled VP6 flow cytometric antibody, stain at room temperature for 20 minutes, wash twice with cold PBS, and detect by flow cytometry.

Immunomodulatory Characteristics of Targeted Lactobacillus:-

In order to detect the effect of VP6 expression on the immune regulatory characteristics of BALB/c mice, female $\mathrm{BALB} / \mathrm{c}$ mice were selected for the experiment, and FCM was used to detect the changes of immune cells in each group after immunization.

Test grouping and immunization procedures: the experiment was divided into PBS, NC8-pSIP409 and NC8pSIP409-pgsA-VP6-Dcpep groups, each group had five mice; the immunization dose was $109 \mathrm{CFU} / 100 \mu \mathrm{L} / \mathrm{mice}$, the first immunization was continuous for three days, two weeks apart, then three days of intensive immunization, and the next seven days of relevant indicators were tested;

The MLN and P P junctions of mice in each group were obtained, and the single cell suspension was prepared and counted.

DCs surface staining: adjusting the concentration of MLN cell suspension to $1.0 * 106 / 100 \mu \mathrm{L}$, adding $100 \mu \mathrm{L}$ APClabeled VP6, PerCP-Cy5.5-labeled CD80 and PE-labeled CD83 flow antibody, incubating at room temperature and avoiding light for 20 minutes, washing twice with PBS, and detecting by flow cytometry; 
Detection of cytokines in T cells: adjusting the concentration of MLN cells to $2 * 106 / 500 \mu \mathrm{L}$ and laying them in 48 well cell culture plate.

FCM to detect the effects of invasive lactic acid bacteria on DCs, T cells and B cells

DCs and B cell surface staining: adjusting the concentration of cell suspension in MLN and P P junction to 106 cells $/ 100 \mu \mathrm{L}$, divided into two casings, one set of VP6 labeled with APC from mouse, the other set of CD40 labeled with FITC and CD80 labeled with PerCP-Cy5.5 were used to label DCs; the other set of B220 antibody labeled with APC was used to label B cells, chamber. After incubation for 20 minutes, PBS was washed twice at $4^{\circ} \mathrm{C}$ for 2000 $\mathrm{rpm} / 5 \mathrm{~min}$. The cell suspension was retained for about $300 \mu \mathrm{L}$. The cells were transferred to the flow tube and detected by flow cytometry.

Intracellular cytokine staining of spleen cells: adjusting the concentration of spleen cells to $2 * 106 / 500 \mu \mathrm{L}$, adding PMA with final concentration of $40 \mathrm{ng} / \mathrm{L}$, ionomycin with $1 \mathrm{ug} / \mathrm{mL}$, blocker of $1 \mathrm{~L}$, incubation stimulation for $5 \mathrm{~h}$ at $37^{\circ} \mathrm{C} 5 \% \mathrm{CO} 2$ incubator; collecting cells in $1.5 \mathrm{~mL}$ centrifuge tube, $4^{\circ} \mathrm{C} 2000 \mathrm{rpm} / 5 \mathrm{~min}$, discarding supernatant; $1 \mathrm{~mL}$ PBS; One time, $4 \mu \mathrm{L}$ PBS was suspended and $10 \mu \mathrm{L}$ corresponding antibodies CD3e and CD4 were added to each tube for 30 minutes at room temperature; PBS was washed twice, and the supernatant was discarded at $4{ }^{\circ} \mathrm{C} 2000$ $\mathrm{rpm} / 5 \mathrm{~min}$, mixed with $250 \mathrm{~L}$ Fixation/permeation Solution, and avoided light for 20 minutes at $4^{\circ} \mathrm{C} 2000 \mathrm{~m} / 5 \mathrm{~min}$; the supernatant was discarded at $4^{\circ} \mathrm{C} ; 1 \mathrm{X} \mathrm{BD}$ perm/wash. Buffer, $2000 \mathrm{rpm} / 5 \mathrm{~min}$, discarded supernatant, washed twice, and finally fixed volume $100 \mu \mathrm{L}$; each tube was added corresponding antibodies IFN-gamma, IL-4 and IL$17 \mathrm{~A}$, stained for 30 minutes at $4^{\circ} \mathrm{C} ; 1 \mathrm{~mL} 1 \mathrm{X}$ BD perm/wash buffer was washed once, PBS was washed twice, fixed volume to $300 \mu \mathrm{L}$, and transferred into the flow tube for detection by flow cytometry.

ELISA to detect the expression of cytokines in serum

The serum was thawed at $-80^{\circ} \mathrm{C}$, centrifuged at $4^{\circ} \mathrm{C}$ and 4000 rpm for 15 minutes. The mice were tested with IFNgamma, IL-4 and IL-17A ELISA kits according to the kit instructions, and the absorbance was measured at A450 $\mathrm{nm}$.

ELISA to detect the expression of specific antibodies in serum and intestinal lavage fluid:Coating: VP6 protein was diluted with ELISA coating solution, and the concentration of VP6 protein was adjusted to $2 \mathrm{~g} / \mathrm{mL}$. $100 \mu \mathrm{L}$ was added into each hole of 96 -well ELISA culture plate and stayed overnight at $4^{\circ} \mathrm{C}$. Washing: $300 \mu \mathrm{L}$ PBST containing $0.05 \%$ Tween- 20 was added to each hole, and washed once every 5 minutes for 3 times. Sealing PBS containing $2 \%$ BSA was added to each hole, and the temperature chamber at $37^{\circ} \mathrm{C}$ was closed for 2 hours, $150 \mu \mathrm{L} /$ hole. Washing: adding PBST to each hole for 5 minutes, washing three times, $300 \mu \mathrm{L} /$ hole. Primary antibody: add the samples of serum and intestinal lavage fluid to be tested, dilute them with the above-mentioned blocking fluid in turn, and feel them for 2 hours at $37^{\circ} \mathrm{C}$. Wash: add $300 \mu \mathrm{L}$ PBST to each hole, wash for 5 minutes each time, three times in total. Antibody II: Serum and intestinal lavage fluid were incubated with total $\lg G$ and $\operatorname{sg} \mathrm{A}$ antibodies respectively. The diluted antibodies were incubated with $50 \mu \mathrm{L}$ per pore for 1 hour at $37^{\circ} \mathrm{C}$. StrepiavidinHRP diluted with $50 \mu \mathrm{L}$ per hole for 30 minutes. Washing: add PBST to each hole, wash $300 \mu \mathrm{L} / \mathrm{hole}$, wash once every 5 minutes, three times altogether. Substrate addition: $200 \mu$ LTMB was added into each pore, and the lightshielding effect was 10 minutes at $37^{\circ} \mathrm{C}$ Termination reaction: adding $20 \% \mathrm{H} 2 \mathrm{SO} 4$ termination solution, 50 $\mu \mathrm{L} /$ pore, $450 \mathrm{~nm}$, OD value of each pore was detected by enzyme labeling instrument.

\section{Safety Detection of Lactobacillus Expressing recombinant strain VP6:-}

PMA, ionomycin and blocker were added to stimulate for 5 hours. Flow antibodies CD3e and CD4 were added to stain the surface, fix the perforation membrane, and add IFN-gamma, IL-4 and IL-17. A was stained with cytokines and detected by flow cytometry.

Detection of cytokines in B cells: adjust the concentration of PP junction single cell suspension to $1 * 106 / 100 \mu \mathrm{L}$, add $10 \mu \mathrm{L}$ of APC labeled anti-rat B220, and keep away from light at room temperature for 30 minutes; wash PBS twice, discard the supernatant at $4^{\circ} \mathrm{C} 2000 \mathrm{rpm} / 5 \mathrm{~min}$, add fixative solution to fix and perforate the membrane according to the previous method, add $10 \mu \mathrm{L}$ to each tube after perforation. FITC-labeled anti-mouse IgA antibody was washed once with penetrating solution, twice with PBS, at a constant volume of $300 \mu \mathrm{L}$, and detected by flow cytometry. 


\section{Data Analysis:-}

Flowjo 7.6.1 software was used for flow cytometry analysis, GraphPad Prism 5 software was used for mapping and statistical data, and one-way ANOVA was used for statistical analysis of the differences between groups $(*, \mathrm{P}<$ $0.05 ; * *, \mathrm{P}<0.01 ; * * *, \mathrm{P}<0.001)$.

\section{Results:-}

PCR results of VP6

The PCR template was amplified from the VP6 based template and detected by agarose gel electrophoresis. As shown in Fig. 1, a clear band of 1356bp was found, which was in line with the expected size. The size of 1356bp was $0.8 \%$.

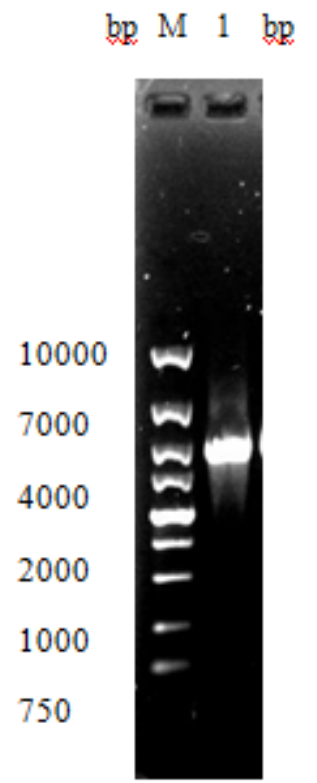

Fig. 1 PCR amplification of VP6 M: DL2000marker; 1 : The result of VP6 by PCR

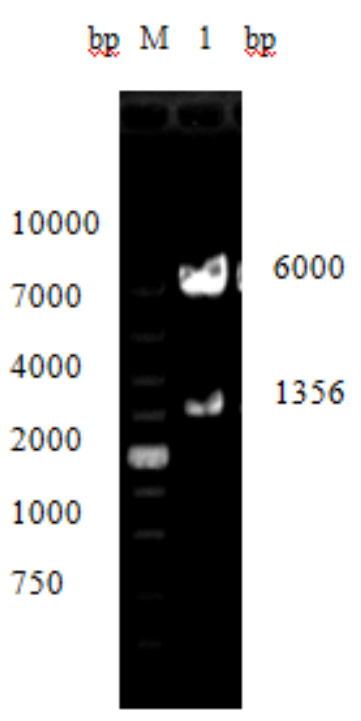

Fig. 2 Identification of plasmid pSIP409 pgsA-VP6-Dcpep by enzyme digestion M: DL10000 Marker ; 1 : Identification of plasmid by enzyme digestion

Identification of plasmid pSIP409-pgsA-VP6-Dcpep by restriction enzyme digestion:-

The recombinant plasmid was identified by single digestion using Hind III. As shown in Figure 2, two distinct bands were identified, which were in accordance with the expected size. The homology of the recombinant plasmid was $100 \%$ by sequencing by biotechnology company, indicating that the recombinant plasmid was successfully constructed.

\section{Western blot results of VP6:-}

In order to detect the expression of VP6, we extracted the cell wall of lactic acid bacteria, as shown in Figure 3. There was a clear protein band at 38KDa, while the negative control NC8-pSIP409 had no imprinting band after protein imprinting analysis. The results showed that VP6 was expressed on the cell wall surface of Lactobacillus plantarum NC8, which was reactive. 


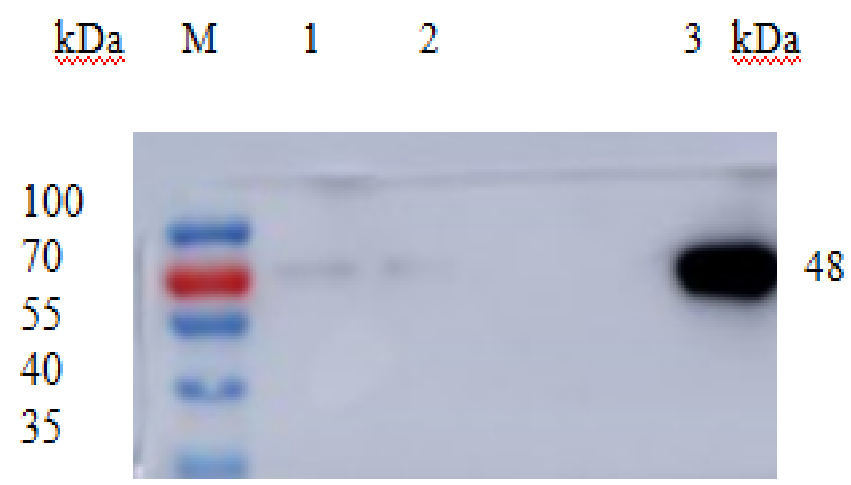

\section{Fig. 3 The result of westem blot M: Low molecular weight protein standard; 1: NC8- pSIP409; 2: NC8-pSIP409 pgsA-VP6-Dcpep}

\section{Detection results of adhesion and invasiveness of targeted lactic acid bacteria to BMDCs:-}

In order to detect the adhesion and invasion of VP6-expressing targeting lactic acid bacteria to BMDCs, we stimulated BMDCs by targeting lactic acid bacteria. Because VP6 expressed on the surface of targeting lactic acid bacteria can specifically bind to CDs receptors on BMDCs, there are two groups for detecting specificity, one group is NC8-pSIP409-pgsA-VP6-Dcpep group, the other is NC8-pSIP409-pgsA group. Anti-VP6 antibody can bind to CDs receptor on BMDCs before stimulation. Targeted lactic acid bacteria are added at this time, which led to the weakening of cell adhesion and invasion due to competition. As shown in Figure 4, the adhesion and invasion rates of targeted lactic acid bacteria NC8-pSIP409-pgsA-VP6-Dcpep to BMDCs were significantly higher than those of blank carrier NC8-pSIP409-pgsA $(\mathrm{P}<0.001)$, and the adhesion and invasion rates were significantly higher than those of NC8-pSIP409-pgsA-VP6-Dcpep anti-VP6 (P < 0.01, P < 0.001), suggesting that targeted lactic acid bacteria could be specific to BMDCs. Heterosexual binding leads to a significant increase in adhesion and invasion.
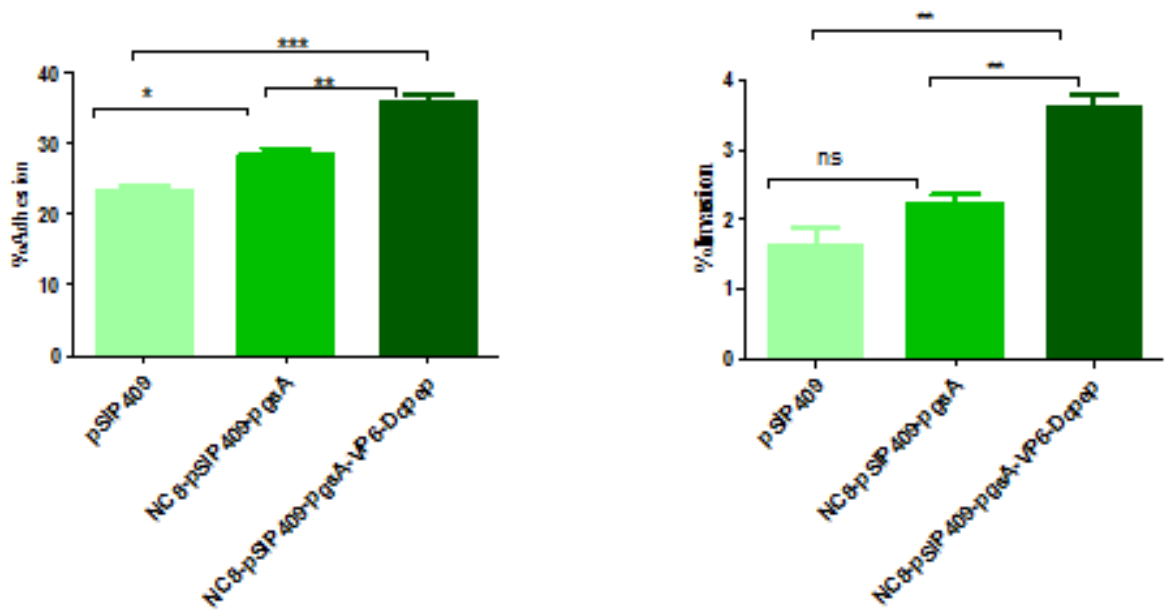

Fig.4:- The comparation of adhesion and invasion of targeting L. plantarum to BMDCs.

\section{Observation of the invasive effect of targeted lactic acid bacteria on BMDCs by transmission electron microscopy:-}

The above results have shown that the targeted lactobacillus has certain adhesion and invasion ability. In order to observe the invasion state more intuitively, we used transmission electron microscopy to observe. As shown in Figure 5, the red arrow represents part of Lactobacillus plantarum which enters the cytoplasm. The scale is 2 micrometers. It can be seen that the expression of VP6 is expressed. After stimulation of BMDCs by 1c-targeting lactic acid bacteria, the number of bacteria in the cytoplasm was significantly more than that in NC8-pSIP409-pgsA group. At this time, there was no significant difference in cell morphology and structure between PBS group and 
NC8-pSIP409-pgsA group. At one time, the target Lactobacillus could also enter BMDCs. Compared with the empty carrier group, the number of entering cells increased significantly $(\mathrm{P}<0.01)$.
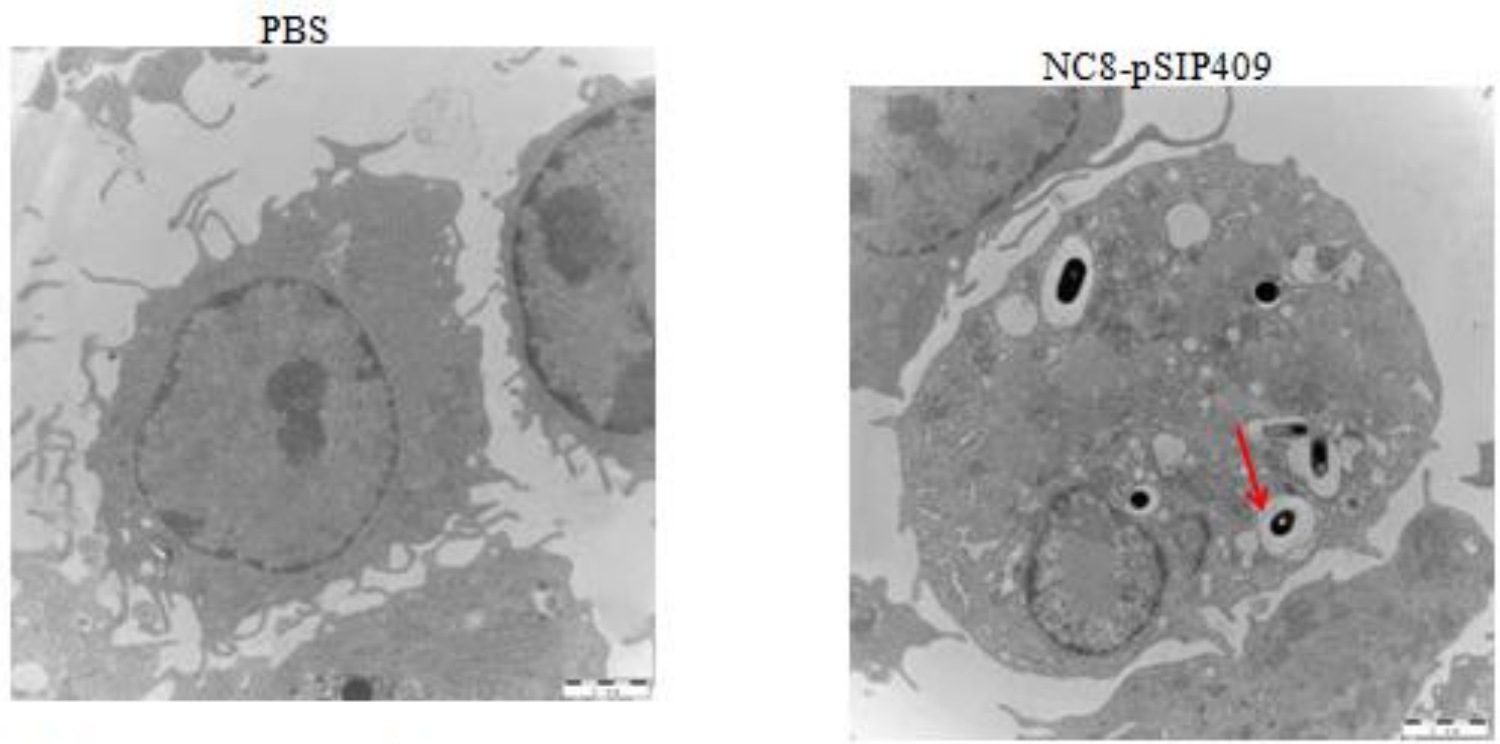

\section{NC8-pSIP409-pgsA-VP6-Dcpep}
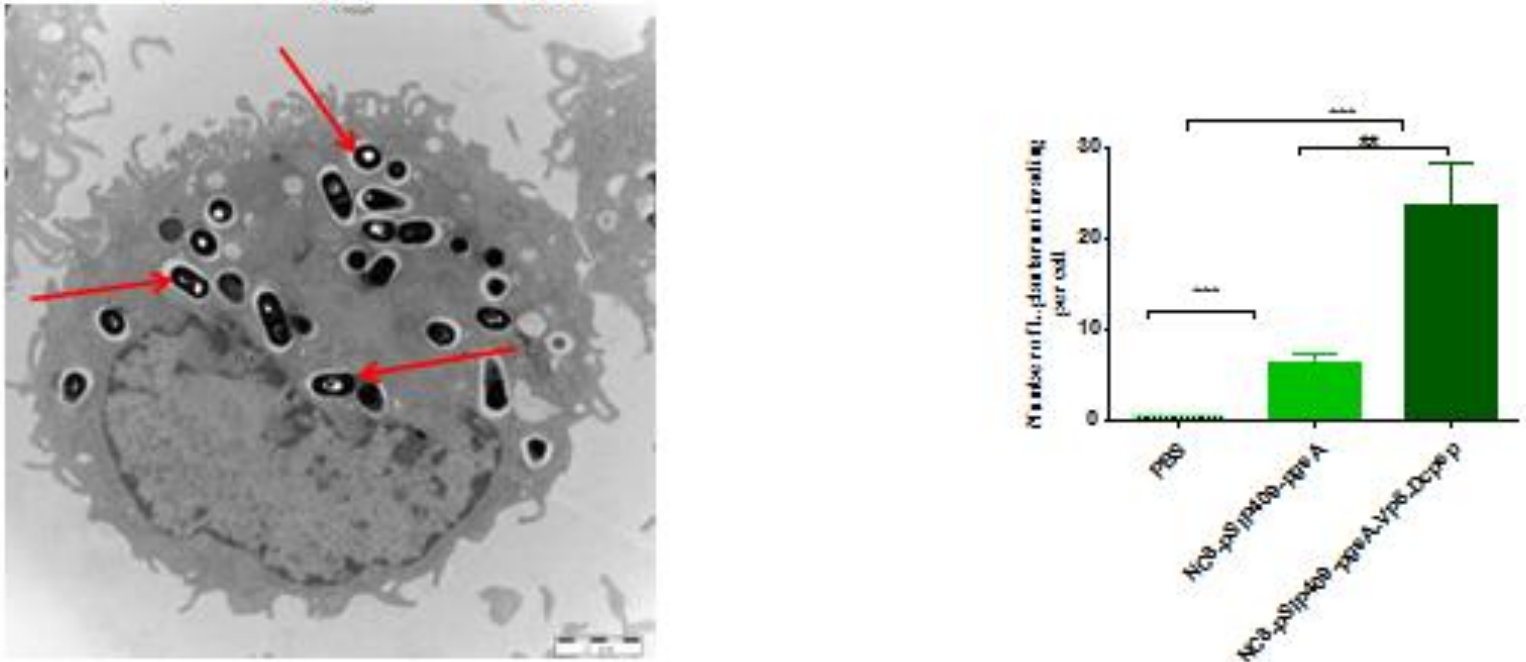

Fig 5:- Invasion assay of the strains to BMDCs was observed by transmission electron microscopy.

\section{Detection of GFP delivery ability of lactic acid bacteria expressing VP6 in vitro:-}

Targeted lactobacillus can specifically bind to VP6 receptor on BMDCs, so it belongs to a new delivery vector, which can deliver plasmids to cells. To further verify the efficiency of plasmid delivery, eukaryotic plasmids pValac-GFP was electrochemically transformed into NC8-pSIP409-pgsA and NC8-pSIP409-pgsA-VP6-Dcpep, respectively. Two double-plasmid lactic acid bacteria 409/pValac-GFP and 409a/pValac-GFP were constructed. BMDCs were stimulated by lactic acid bacteria containing double plasmids. For 409a/pValac-GFP group, the MFI of GFP in VP6 DCs was significantly higher than that in 409/pValac-GFP group $(\mathrm{P}<0.01)$. There was no significant difference compared with the anti-VP6 antibody group, but there was an upward trend. As shown in Figure 6, this experiment shows that lactic acid bacteria expressing VP6 in BMDCs can improve the delivery efficiency of eukaryotic plasmid pValac-GFP and is a good delivery vector. 

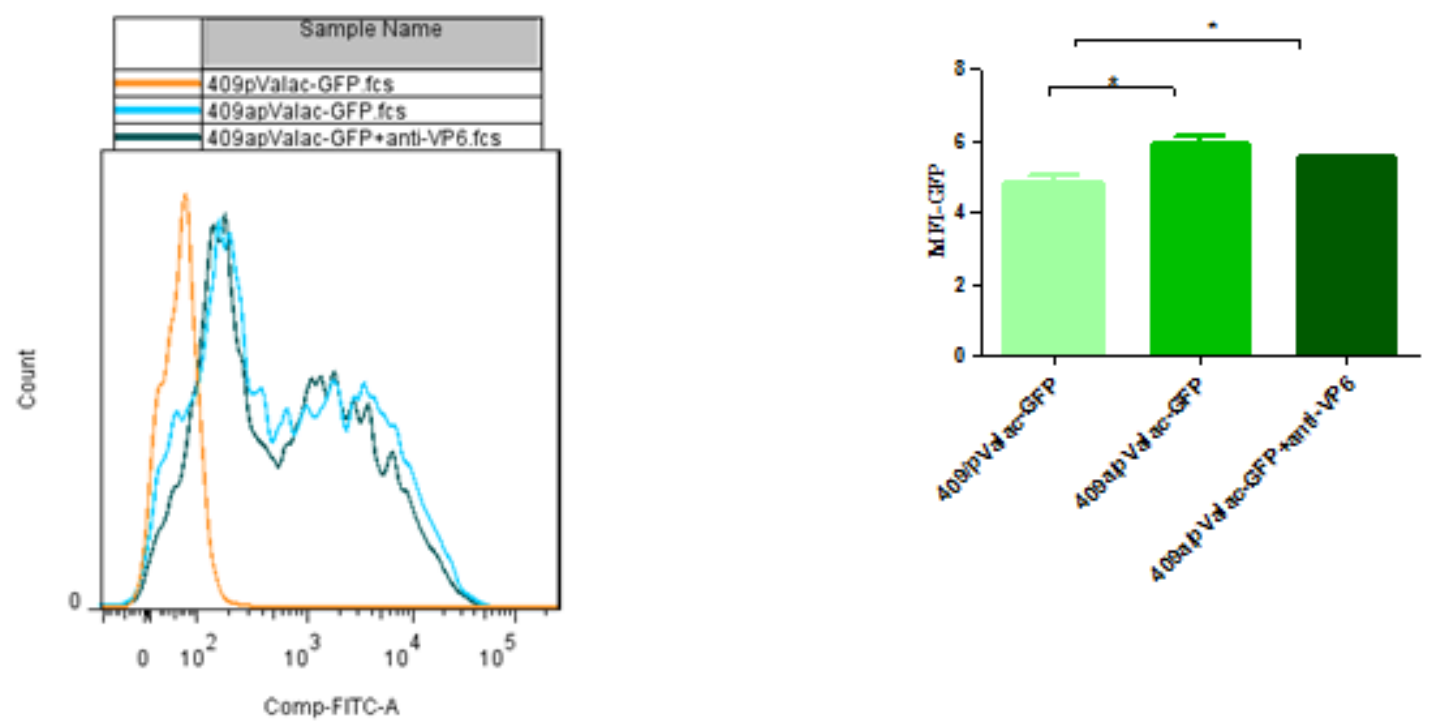

Fig 6:- Expression of $\mathrm{V}^{+} \mathrm{GFP}^{+}$in BMDCs after co-culturing with 409/pValac-GFP and 409a/pValac-GFP strains for 36.

Detection results of immunoregulatory properties of BALB/c by lactic acid bacteria expressing VP6:-

To further evaluate the effects of targeted Lactobacillus on immune regulation in mice, the changes of DCs, T cells and B cells in MLN and P P cells of mice were detected by FCM after strengthening immunization. As shown in Figure 7, targeting lactic acid bacteria significantly increased the percentage of CD80+and CD83+in DCs of MLN $(\mathrm{P}<0.001)$, thus promoting the differentiation and maturation of DCs; DCs acquired antigens and delivered them to $\mathrm{T}$ cells, so we then detected the intracellular cytokines IFN-gamma+, IL-4+and IL-17A of CD4+T cells in MLN.+ As shown in Figure 8, the expression of IL-4+ and IL-17A + in CD4 + T cells increased significantly $(\mathrm{P}<0.001, \mathrm{P}$ $<0.01)$. For IFN-gamma + , there was no significant difference, indicating that targeting lactic acid bacteria could promote the differentiation of CD4 + T cells into Th 2 and Th17; T cells would deliver antigens to B cells, and we continued to examine them. The expression level of B220 + IgA + B cells in PP junction was measured. As shown in Figure 9, the expression level of targeted Lactobacillus group increased significantly $(\mathrm{P}<0.001)$, indicating that it could promote the production of antibodies. In conclusion, targeting lactobacillus has good immunomodulatory effect.
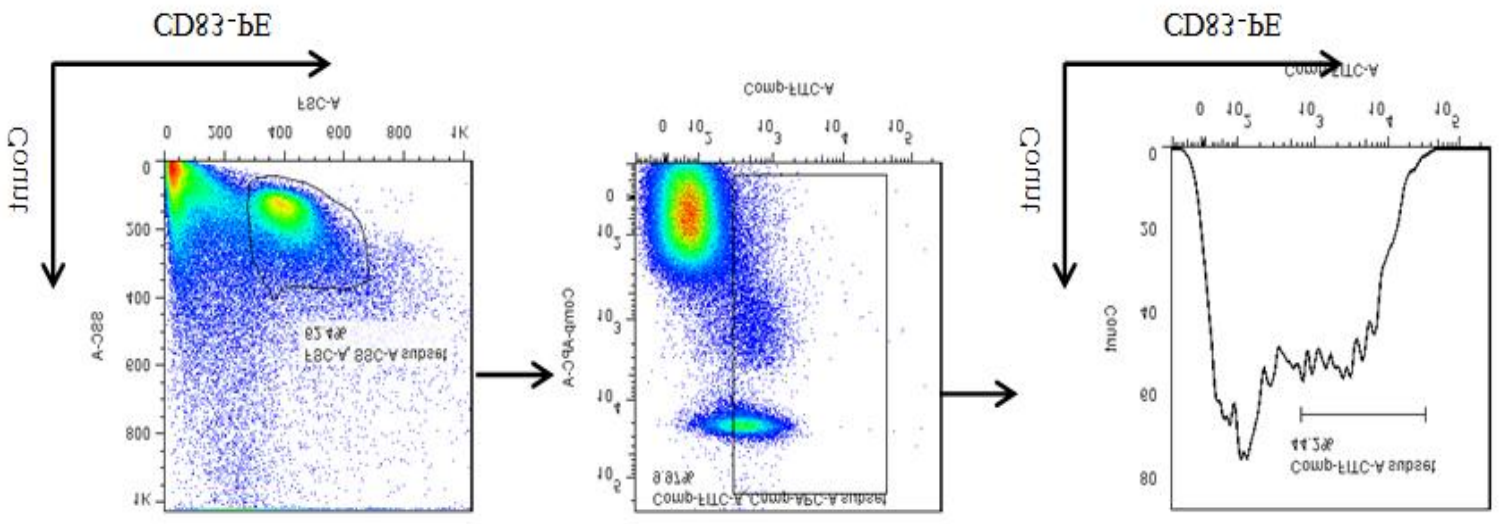

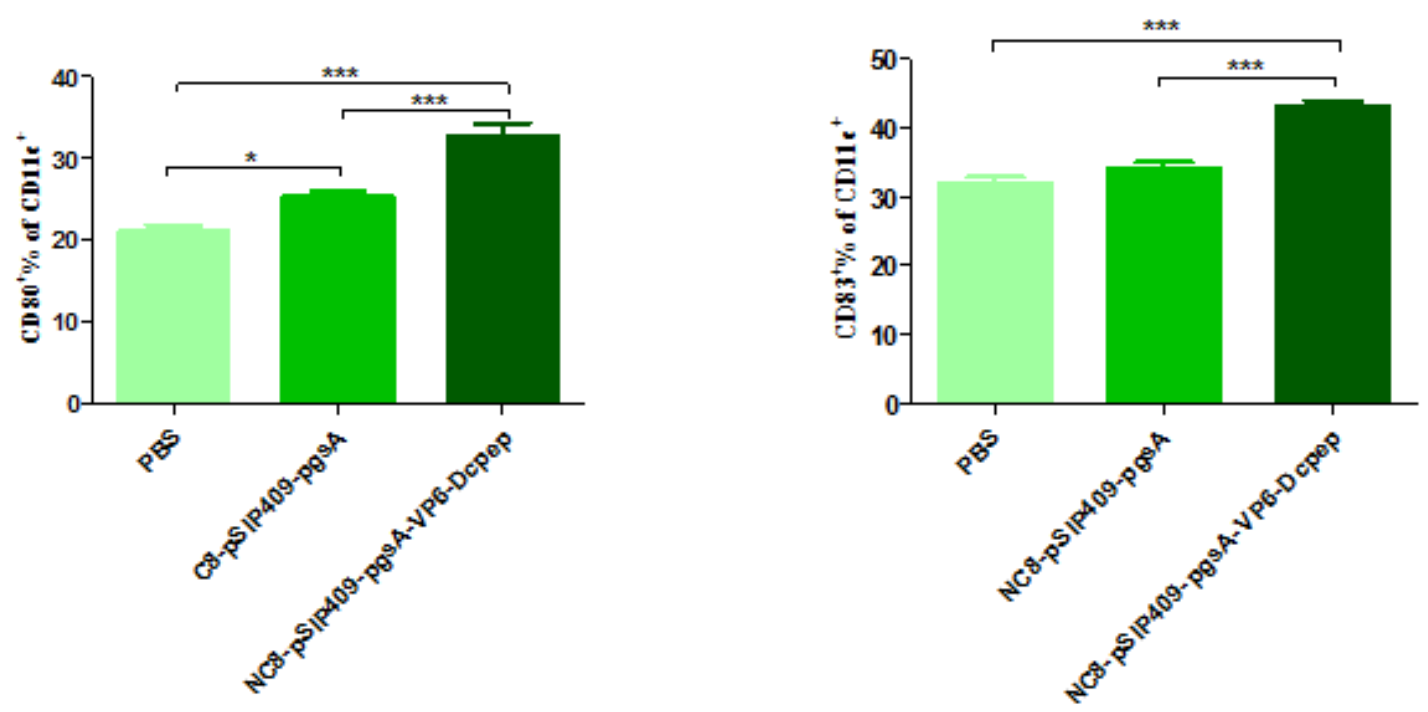

Fig 7:- The influence of L.plantarum expressing VP6 on DCs.

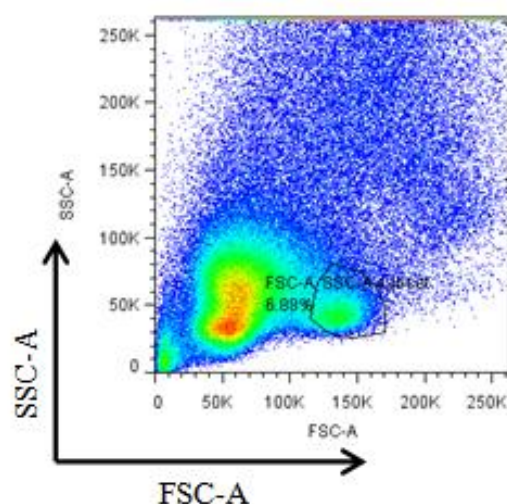

FSC-A

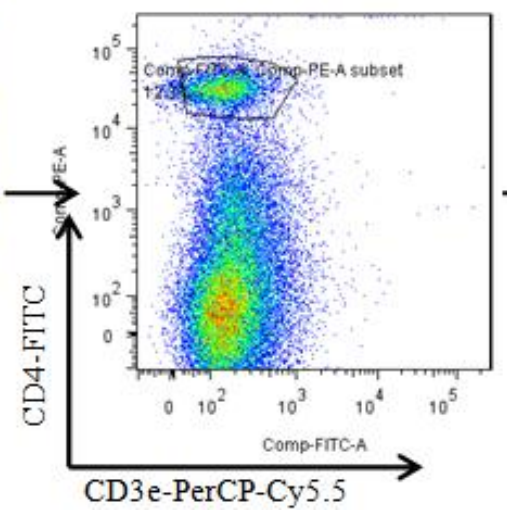

CD3e-PerCP-Cy 5.5

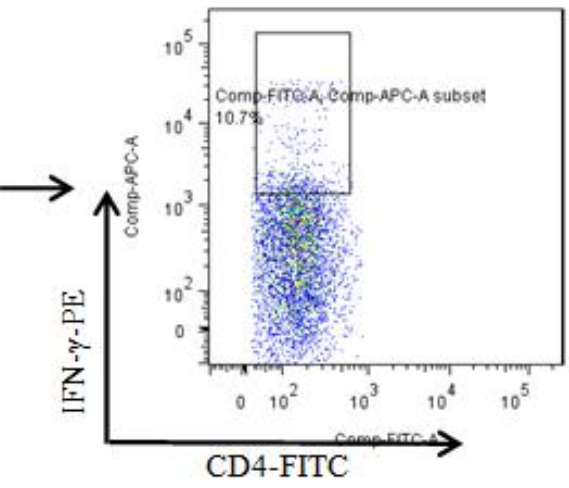

PB S

NC 8-pSIP 409-pgsA

NC 8-pSIP 409-pgsA -VP6-Dcpep

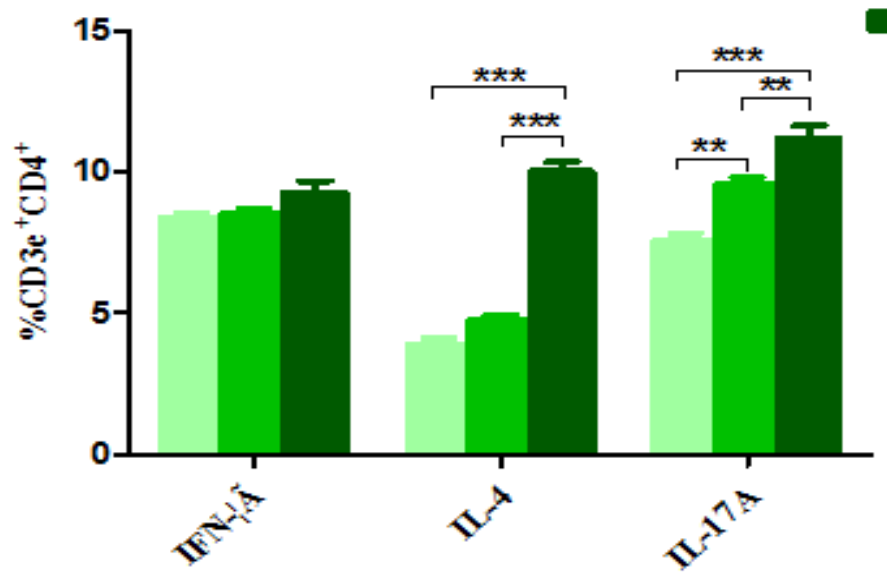

Fig 8:- The influence of L.plantarum expressing VP6 on CD4 ${ }^{+}$T cells. 


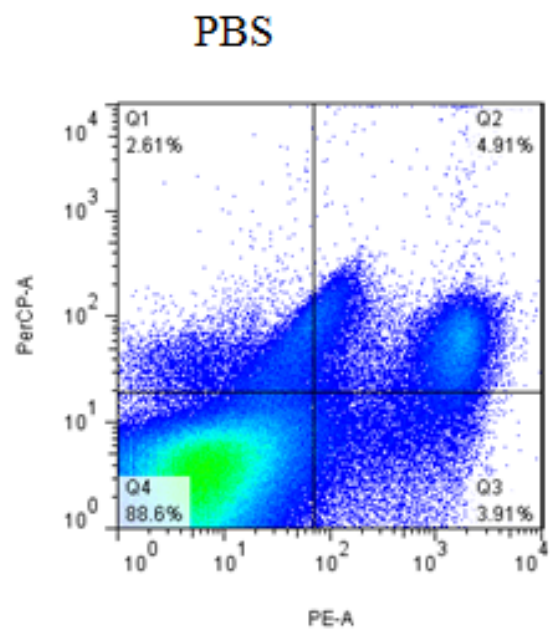

NC8-pSIP409-pgsA-VP6-Dcpep

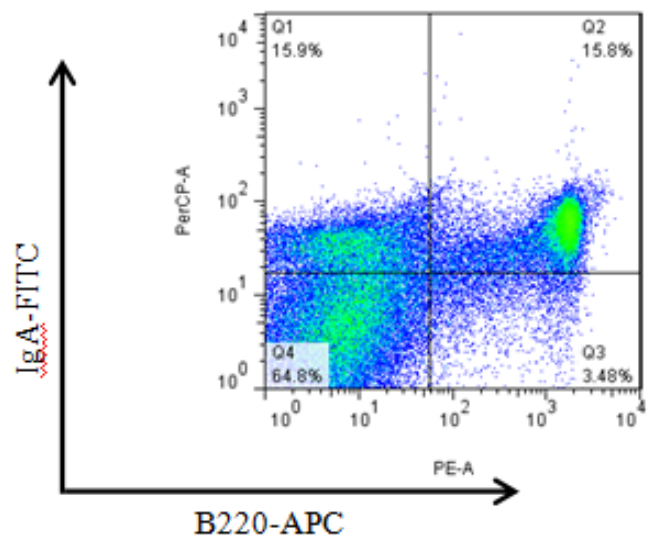

NC8-pSIP409-pgsA
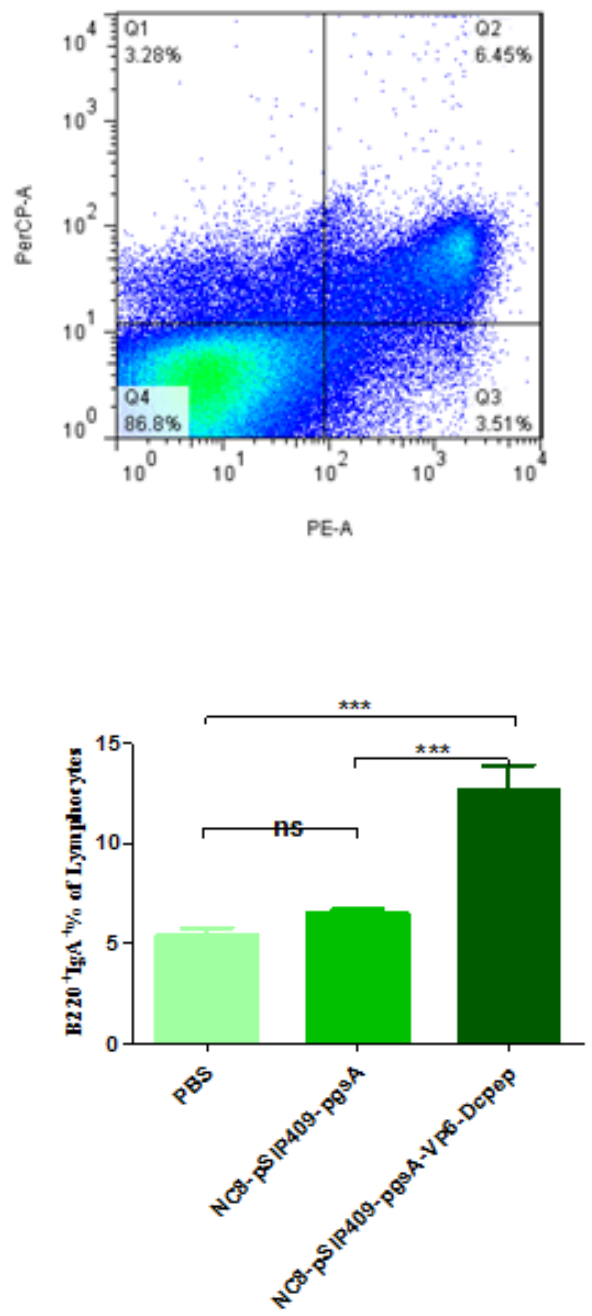

Fig 9:- The effect of L.plantarum expressing VP6 on B cells.

\section{Discussion:-}

The main sources of acute diarrhea in piglets are porcine rotaviruses, and infection with these viruses can lead to mild to severe diarrhea with high mortality and morbidity rates. Porcine rotavirus infection has been an economic concern worldwide among pig breeders. The major prophylactic method for the prevention and control of porcine rotavirus infections is vaccination. There are a number of advantages offered by mucosal immunization that are not offered by other routes of antigen delivery, such as the ability to stimulate both the systemic and local immune responses, cost effectiveness and the ease of administration $(3,18,27,20)$.

Lactic acid bacteria are often a promising candidate strain in new and safe vaccine studies. Lactic acid bacteria targeting DCs have increased the expression of +GFP+ BMDCs due to increased cellular uptake, indicating that this newly constructed vector is a good choice for future DNA vaccines or mucosal delivery vehicles. Since the immune response produced by the body is initiated by the activation of DCs, which stimulates the differentiation of T cells and the activation of B cells, we evaluated the effects of lactic acid bacteria targeting DCs on DCs, T cells and B cells. Lactic acid bacteria targeting DCs can induce the activation of DCs (31). Consistent with the results of this study, our newly constructed strain NC8-pSIP409-pgsA-VP6-Dcpep can effectively stimulate the maturation of DCs. Since the cytokines IFN- $\gamma$, IL-4 and IL-17A represent the Th1, Th2 and Th17 subpopulations of helper CD4+ $\mathrm{T}$ cells, respectively, we also evaluated the expression of the above three cytokines in CD4+ T cells using FCM. An increase in the expression of IL-4 and IL-17A indicates that targeting lactic acid bacteria can promote the differentiation of CD4+ T cells into Th2 and Th17, and has a cellular immune effect. On the other hand, we also 
evaluated the humoral immune response, namely the activation of B cells and the expression level of intracellular IgA antibodies. The results confirmed a significant increase in the percentage of $\operatorname{Ig} A+B 220+B$ cells, indicating a certain immunoregulatory function on the host immune system.

\section{Conclusion:-}

The expression of VP6 can enhance the adhesion and invasion ability of strains to BMDCs in vitro, and can improve the expression of GFP in cells carrying pValac-GFP plasmid. The expression of VP6 in vivo can promote the differentiation of DCs, promote the polarization of CD4+ T cells to Th2 and Th17 and promote the percentage of PP-B220+IgA+B cells.

\section{Declarations:-}

Ethics approval and consent to participate:-

This study was carried out in agreement with the principles established by Jilin Agriculture University Changchun China and guide for the use of laboratory and care animals and all experimental protocols were approved by a Jilin Agriculture University (No. JLAU08201007).

\section{Consent for publication:-}

Not applicable

Availability of data and materials: will be provided after acceptance

\section{Competing interests:}

1. Author1 declares that she has no conflict of interest.

2. Author 2 declares that he has no conflict of interest.

3. Author 3 declares that she has no conflict of interest.

4. Author 4 declares that he has no conflict of interest

\section{Funding:-}

This work was supported by The National Key Research and Development Program of China (2017YFD0501000). Authors' contributions:

1. Author 1 SMS -searching data, wrote manuscript and acted as corresponding author

2. Author $2 \mathrm{WY}$-editing manuscript

3. Author $3 \mathrm{GY}$ - editing the manuscript and supervision of the manuscript

4. Author $4 \mathrm{CW}$ - editing the manuscript and supervision of the manuscript

5. All authors have read and approved the manuscript:-

\section{Acknowledgement:-}

We are thankful to the Jilin Agricultural University for the internet to download Data for this study.

\section{References:-}

1. Ambily, R., Mini, M., John, K. \& Nair, G.K. (2009) First report of bovine rotavirus from Kerala. Biosciences, Biotechnology Research Asia, 6: 245-49.

2. Anbazhagan, K., Sasikumar, P., Gomathi, S., Priya, H.P. \& Selvam, G.S. (2013) In vitro degradation of oxalate by recombinant Lactobacillus plantarum expressing heterologous oxalate decarboxylase. 115: 880-87.

3. Azegami, T., Yuki, Y. \& Kiyono, H. (2014) Challenges in mucosal vaccines for the control of infectious diseases. International immunology, 26: 517-28.

4. Caggianiello, G., Kleerebezem, M. \& Spano, G. (2016) Exopolysaccharides produced by lactic acid bacteria: from health-promoting benefits to stress tolerance mechanisms. Applied microbiology and biotechnology, 100: 3877-86.

5. Cai, R., Jiang, Y., Yang, W., Yang, W., Shi, S., Shi, C., Hu, J., Gu, W., Ye, L., Zhou, F., Gong, Q., Han, W., Yang, G. \& Wang, C.J.J.M.B. (2016) Surface-Displayed IL-10 by Recombinant Lactobacillus plantarum Reduces Th1 Responses of RAW264.7 Cells Stimulated with Poly(I:C) or LPS. 26: 421-31.

6. Chanos, P. \& Mygind, T. (2016) Co-culture-inducible bacteriocin production in lactic acid bacteria. Applied microbiology and biotechnology, 100: 4297-308. 
7. Chen, C.-C., Chiu, C.-H., Lin, T.-Y., Shi, H.N. \& Walker, W.A. (2009) Effect of Probiotics Lactobacillus acidophilus on Citrobacter rodentium Colitis: The Role of Dendritic Cells. Pediatric Research, 65: 169-75.

8. Chitambar, S.D., Arora, R., Kolpe, A.B., Yadav, M.M. \& Raut, C.G. (2011) Molecular characterization of unusual bovine group A rotavirus G8P[14] strains identified in western India: Emergence of P[14] genotype. Veterinary Microbiology, 148: 384-88.

9. Clark, B. \& Desselberger, U. (1988) Myristylation of rotavirus proteins. The Journal of general virology, 69 ( Pt 10): 2681-6.

10. Dewey, C., Carman, S., Pasma, T., Josephson, G. \& Mcewen, B. (2003) Relationship between group A porcine rotavirus and management practices in swine herds in Ontario. The Canadian Veterinary Journal, 44: 649-53.

11. Di-Qiu, L., Jun-Wei, G., Xin-Yuan, Q., Yan-Ping, J., Song-Mei, L. \& Yi-Jing, L. (2012) High-level mucosal and systemic immune responses induced by oral administration with Lactobacillus-expressed porcine epidemic diarrhea virus (PEDV) S1 region combined with Lactobacillus-expressed N protein. Applied microbiology and biotechnology, 93: 2437-46.

12. Estes, M.K. \& Cohen, J. (1989) Rotavirus gene structure and function. Microbiological reviews, 53: 410-49.

13. Gachanja, E., Buza, J. \& Petrucka, P. (2016) Prevalence of Group A Rotavirus in Piglets in a Peri-Urban Setting of Arusha, Tanzania. Journal of Biosciences and Medicines, 04: 37-44.

14. Ghosh, S., Samajdar, S., Sinha, M., Kobayashi, N., Taniguchi, K. \& Naik, T.N. (2008) Molecular characterization of rare bovine group A rotavirus G15P[11] and $\mathrm{G} 15 \mathrm{P}[21]$ strains from eastern India: identification of simian SA11-like VP6 genes in G15P[21] strains. Virus genes, 37: 241-9.

15. Higgins, J.P., Higgins, S.E., Wolfenden, A.D., Henderson, S.N., Torres-Rodriguez, A., Vicente, J.L., Hargis, B.M. \& Tellez, G. (2010) Effect of lactic acid bacteria probiotic culture treatment timing onSalmonella Enteritidis in neonatal broilers. Poultry Science, 89: 243-47.

16. Hull, J.J., Marthaler, D., Rossow, S., Ng, T.F.F., Montmayeur, A.M., Magana, L., Moon, S.-S. \& Jiang, B. (2016) Genomic Sequence of the First Porcine Rotavirus Group H Strain in the United States. Genome Announcements, 4: e01763-15.

17. Kava, R. (2018) Rotavirus Vaccines Do More Than Prevent Diarrhea. American Council on Science and Health.

18. Kim, S.-H. \& Jang, Y.-S. (2017) The development of mucosal vaccines for both mucosal and systemic immune induction and the roles played by adjuvants. Clin Exp Vaccine Res, 6: 15-21.

19. Malik, Y.S., Sharma, K., Vaid, N., Chakravarti, S., Chandrashekar, K.M., Basera, S.S., Singh, R., Minakshi, Prasad, G., Gulati, B.R., Bhilegaonkar, K.N. \& Pandey, A.B. (2012) Frequency of group A rotavirus with mixed $\mathrm{G}$ and $\mathrm{P}$ genotypes in bovines: predominance of $\mathrm{G} 3$ genotype and its emergence in combination with G8/G10 types. Journal of Veterinary Science, 13: 271-78.

20. Mannam, P., Jones, K.F. \& Geller, B.L. (2004) Mucosal vaccine made from live, recombinant Lactococcus lactis protects mice against pharyngeal infection with Streptococcus pyogenes. Infect Immun, 72: 3444-50.

21. Manuja, B.K., Prasad, M., Manuja, A., Gulati, B.R. \& Prasad, G. (2008) A novel genomic constellation (G10P[3]) of group A rotavirus detected from buffalo calves in northern India. Virus research, 138: 36-42.

22. Marthaler, D., Rossow, K., Gramer, M., Collins, J., Goyal, S., Tsunemitsu, H., Kuga, K., Suzuki, T., Ciarlet, M. \& Matthijnssens, J. (2012) Detection of substantial porcine group B rotavirus genetic diversity in the United States, resulting in a modified classification proposal for G genotypes. Virology, 433: 85-96.

23. Matthijnssens, J., Ciarlet, M., Mcdonald, S.M., Attoui, H., Banyai, K., Brister, J.R., Buesa, J., Esona, M.D., Estes, M.K., Gentsch, J.R., Iturriza-Gomara, M., Johne, R., Kirkwood, C.D., Martella, V., Mertens, P.P., Nakagomi, O., Parreno, V., Rahman, M., Ruggeri, F.M., Saif, L.J., Santos, N., Steyer, A., Taniguchi, K., Patton, J.T., Desselberger, U. \& Van Ranst, M. (2011) Uniformity of rotavirus strain nomenclature proposed by the Rotavirus Classification Working Group (RCWG). Archives of virology, 156: 1397-413.

24. Michon, C., Kuczkowska, K., Langella, P., Eijsink, V.G., Mathiesen, G. \& Chatel, J.M. (2015) Surface display of an anti-DEC-205 single chain Fv fragment in Lactobacillus plantarum increases internalization and plasmid transfer to dendritic cells in vitro and in vivo. Microbial cell factories, 14: 95.

25. Narita, J., Okano, K., Tateno, T., Tanino, T., Sewaki, T., Sung, M.-H., Fukuda, H. \& Kondo, A. (2006) Display of active enzymes on the cell surface of Escherichia coli using PgsA anchor protein and their application to bioconversion. Applied microbiology and biotechnology, 70: 564-72.

26. Nataraju, S.M., Chattopadhyay, U.K. \& Krishnan, T. (2009) A study on the possibility of zoonotic infection in rotaviral diarrhoea among calves and buffalo calves in and around Kolkata, India. European review for medical and pharmacological sciences, 13: 7-11.

27. Patel, H., Yewale, C., Rathi, M.N. \& Misra, A. (2014) Mucosal immunization: a review of strategies and challenges. Critical reviews in therapeutic drug carrier systems, 31: 273-303. 
28. Paul, P.S. \& Lyoo, Y.S. (1993) Immunogens of rotaviruses. Veterinary Microbiology, 37: 299-317.

29. Ren, C., Zhang, Q., Wang, G., Ai, C., Hu, M., Liu, X., Tian, F., Zhao, J., Chen, Y., Wang, M., Zhang, H. \& Chen, W. (2014) Modulation of peanut-induced allergic immune responses by oral lactic acid bacteria-based vaccines in mice. Applied microbiology and biotechnology, 98: 6353-64.

30. Shaw, A.L., Rothnagel, R., Zeng, C.Q.Y., Lawton, J.A., Ramig, R.F., Estes, M.K. \& Prasad, B.V.V. (1996) Rotavirus structure: interactions between the structural proteins. In: Chiba, S., Estes, M.K., Nakata, S. \& Calisher, C.H. eds. Viral Gastroenteritis. Vienna: Springer Vienna.

31. Sun, Y., Qian, J., Xu, X., Tang, Y., Xu, W., Yang, W., Jiang, Y., Yang, G., Ding, Z., Cong, Y. \& Wang, C. (2018) Dendritic cell-targeted recombinantLactobacilli induce DC activation and elicit specific immune responses against G57 genotype of avian H9N2 influenza virus infection. Veterinary microbiology, 223: 9-20.

32. Svensson, L., Grahnquist, L., Pettersson, C.A., Grandien, M., Stintzing, G. \& Greenberg, H.B. (1988) Detection of human rotaviruses which do not react with subgroup I- and II-specific monoclonal antibodies. Journal of clinical microbiology, 26: 1238-40.

33. Vlasova, A.N., Amimo, J.O. \& Saif, L.J. (2017) Porcine Rotaviruses: Epidemiology, Immune Responses and Control Strategies. 9: 48.

34. Wang, L., Xia, T., Guo, T., Ru, Y., Jiang, Y., Cui, W., Zhou, H., Qiao, X., Tang, L., Xu, Y. \& Li, Y. (2019) Recombinant Lactobacillus casei Expressing Capsid Protein VP60 can Serve as Vaccine Against Rabbit Hemorrhagic Disease Virus in Rabbits. 7: 172.

35. Wilhelm, B., Waddell, L., Greig, J., Rajic, A., Houde, A. \& Mcewen, S.A. (2015) A scoping review of the evidence for public health risks of three emerging potentially zoonotic viruses: hepatitis E virus, norovirus, and rotavirus. Preventive veterinary medicine, 119: 61-79.

36. Wyszyńska, A., Kobierecka, P., Bardowski, J. \& Jagusztyn-Krynicka, E.K. (2015) Erratum to: Lactic acid bacteria-20 years exploring their potential as live vectors for mucosal vaccination. Applied microbiology and biotechnology, 99: 4531-31.

37. Yang, W.-T., Yang, G.-L., Shi, S.-H., Liu, Y.-Y., Huang, H.-B., Jiang, Y.-L., Wang, J.-Z., Shi, C.-W., Jing, Y.B. \& Wang, C.-F. (2017) Protection of chickens against H9N2 avian influenza virus challenge with recombinant Lactobacillus plantarum expressing conserved antigens. Applied microbiology and biotechnology, 101: 4593-603.

38. Yoon, S.-W., Lee, T.-Y., Kim, S.-J., Lee, I.-H., Sung, M.-H., Park, J.-S. \& Poo, H. (2012) Oral administration of HPV-16 L2 displayed on Lactobacillus casei induces systematic and mucosal cross-neutralizing effects in Balb/c mice. Vaccine, 30: 3286-94. 